\title{
IMPLEMENTASI PERATURAN PEMERINTAH (PP) NOMOR 53 TAHUN 2010 TENTANG DISIPLIN PEGAWAI NEGERI SIPIL DI LEMBAGA LAYANAN PENDIDIKAN TINGGI (LL DIKTI) WILAYAH II (STUDI KASUS PASAL 3)
}

\author{
Sunarto, S.H., M.Si. \\ Sekolah Tinggi Ilmu Administrasi Satya Negara Palembang
}

\begin{abstract}
ABSTRAK
Keberadaan sumber daya manusia di dalam suatu instansi memegang peranan yang sangat penting. Tenaga kerja memiliki potensi yang besar untuk menjalankan aktivitas perusahaan. Potensi setiap sumber daya manusia yang ada dalam perusahaan harus dapat dimanfaatkan sebaik-baiknya sehingga mampu memberikan hasil yang maksimal. Perusahaan dan karyawan merupakan dua hal yang saling membutuhkan. Jika karyawan berhasil membawa kemajuan bagi perusahaan, keuntungan yang diperoleh akan dipetik oleh kedua belah pihak. Bagi karyawan, keberhasilan merupakan aktualisasi potensi diri sekaligus peluang untuk memenuhi kebutuhan hidupnya. Adapun bagi perusahaan, keberhasilan merupakan sarana menuju pertumbuhan dan perkembangan perusahaan.
\end{abstract}

Hasil penelitian ini menunjukkan bahwa implementasi Peraturan Pemerintah (PP) Nomor 53 tahun 2010 tentang Disiplin Pegawai Negeri Sipil di Lembaga Layanan Pendidikan Tinggi Wilayah II (Studi Kasus Pasal 3) telah dilaksanakan dengan baik. Peraturan telah dikomunikasikan dengan baik kepada pegawai melalui sosialisasi, sumber daya manusia, sarana prasarana yang memadai, dan diikuti dengan sikap pegawai yang sungguh-sungguh melaksanakan aturan yang berlaku. Faktor penghambat implementasi Peraturan Pemerintah No. 53 Tahun 2010 tentang Disiplin Pegawai Negeri Sipil di LLDIKTI Wilayah II Kota Palembang pelaksanaan Peraturan Pemerintah Nomor 53 Tahun 2010 tidak ditemukan kendala yang berarti. Hal ini tentu saja dapat menjadi landasan yang kuat bagi LLDIKTI Wilayah II untuk terus maju

Kata Kunci: implementasi dan disiplin

ABSTRACT

The existence of human resources in an agency plays a very important role. Manpower has great potential to run company activities. The potential of each human resource in the company must be utilized as well as possible, to provide maximum results. Companies and employees are two things that need each other. If employees are successful in bringing progress to the company, both parties will reap the benefits. For employees, success is an actualization of their potential as well as an opportunity to fulfill their daily needs. As for the company, success is a means to the growth and development of the company.

The results showed that the implementation of Government Regulation (PP) Number 53 of 2010 concerning Civil Servant Discipline in Region II Higher Education Service Institutions (Case Study Article 3) has been carried out well. This is because regulations have been well communicated to employees through socialization, adequate human resources, infrastructure, and followed by the attitude of employees who implement the applicable rules. Inhibiting factors for the Implementation of Government Regulation No. 53 of 2010 concerning the Discipline of Civil Servants in LLDIKTI Region II of Palembang City, the implementation of Government Regulation Number 53 of 2010 did not find significant obstacles. This of course can be a strong foundation for LLDIKTI Region II to move forward 


\section{PENDAHULUAN}

Keberadaan sumber daya manusia di dalam suatu instansi memegang peranan yang sangat penting. Tenaga kerja memiliki potensi yang besar untuk menjalankan aktivitas perusahaan. Potensi setiap sumber daya manusia yang ada dalam perusahaan harus dapat dimanfaatkan sebaikbaiknya sehingga mampu memberikan hasil yang maksimal. Perusahaan dan karyawan merupakan dua hal yang saling membutuhkan. Jika karyawan berhasil membawa kemajuan bagi perusahaan, keuntungan yang diperoleh akan dipetik oleh kedua belah pihak. Bagi karyawan, keberhasilan merupakan aktualisasi potensi diri sekaligus peluang untuk memenuhi kebutuhan hidupnya. Adapun bagi perusahaan, keberhasilan merupakan sarana menuju pertumbuhan dan perkembangan perusahaan.

Sumber daya manusia merupakan satusatunya yang memiliki akal perasaan, keinginan, pengetahuan, dorongan, daya dan karya. Seorang karyawan merupakan investasi paling berharga di dalam organisasi yang menjadi aset utama yang bernilai dan harus diakui keberadaannya sebagai kunci utama-bahkan ada kalanya faktor penentu-keberhasilan suatu organisasi dalam menjalankan visi, misi, dan tujuan organisasi. Itulah sebabnya mengapa peran manusia sangat besar pengaruhnya sebagai motor penggerak (driving force) dan sebagai agen perubahan (agent of change).

Pengembangan sumber daya manusia yang ada dalam lingkup organisasi merupakan suatu proses peningkatan kualitas atau kemampuan manusia dalam rangka mencapai tujuan perusahaan tersebut. Tujuan organisasi dapat diraih semaksimal mungkin apabila didukung dengan kinerja yang baik dari para karyawan. Untuk mendapatkan kinerja yang baik karyawan, maka harus diupayakan pengarahan yang terstruktur dan efektif. Perusahaan harus menggerakkan para karyawannya agar mau bekerja lebih produktif lagi sesuai dengan tujuan perusahaan yang telah ditetapkan.

Pegawai Negeri Sipil (PNS) adalah unsur utama sumber daya manusia yang berperan menentukan keberhasilan penyelenggaraan pemerintah dan pembangunan. Sosok PNS yang mampu memainkan peranan tersebut adalah PNS yang mempunyai kompetensi yang diindikasikan dari sikap disiplin yang tinggi, kinerja yang baik serta sikap dan perilakunya yang penuh dengan kesetiaan dan ketaatan kepada negara, bermoral dan bermental baik, profesional, sadar akan tanggung jawabnya sebagai pelayanan publik, serta mampu menjadi perekat persatuan dan kesatuan bangsa.

Perwujudan pemerintah yang bersih dan berwibawa diawali dengan penegakan disiplin nasional di lingkungan aparatur negara khususnya Pegawai Negeri Sipil. Pegawai negara di Indonesia disebut-sebut masih kurang mematuhi peraturan kedisiplinan pegawai sehingga dapat menghambat kelancaran pemerintahan dan pembangunan nasional. Padahal, Pegawai Negeri Sipil seharusnya menjadi teladan bagi masyarakat secara keseluruhan agar masyarakat dapat percaya terhadap peran PNS.

Berdasarkan uraian di atas, PNS sebagai unsur aparatur negara, khususnya dalam menjalankan roda pemerintah, dituntut untuk melaksanakan fungsi dan tugasnya sebagai abdi negara dan abdi masyarakat. Oleh karena itu, perwujudan dedikasi, rasa tanggung jawab dan kedisiplinan tersebut harus mampu dibuktikan. Martabat dan citra kepegawaian Pegawai Negeri Sipil harus dijunjung tinggi sesuai janji yang tertuang dalam butir ke-5 Panca Prasetya Korpri yang berbunyi: "menegakkan kejujuran, keadilan dan disiplin serta meningkatkan kesejahteraan dan profesionalisme."

Dalam upaya meningkatkan kedisiplinan Pegawai Negeri Sipil, pemerintah Indonesia sebenarnya telah memberikan regulasi, yakni dengan dikeluarkannya Peraturan Pemerintahan Nomor 53 tahun 2010 tentang Peraturan Disiplin Pegawai Negeri Sipil. Tujuan pemberlakuan Peraturan Pemerintah Nomor 53 tahun 2010 tentang Disiplin PNS adalah:

a. Merupakan bagian reformasi birokrasi (bureaucracy reform).

b. Menajamkan ketertiban dan kelancaran pelaksanaan tugas, pokok, dan fungsi PNS.

c. Mendorong peningkatan kinerja dan sikap dan perilaku PNS.

d. Meningkatkan kedisiplinan PNS.

Peraturan Disiplin Pegawai Negeri Sipil adalah peraturan yang mengatur kewajiban, larangan, dan sanksi apabila kewajiban-kewajiban tidak ditaati atau dilanggar oleh Pegawai Negeri Sipil. Dengan maksud untuk mendidik dan membina, Pegawai Negeri Sipil yang melakukan pelanggaran atas kewajiban dan larangan dikenakan sanksi berupa hukuman disiplin.

Peraturan Pemerintah Nomor 53 menyebutkan bahwa hukuman disiplin berat sebagaimana dimaksud dalam pasal 3 ayat 11 dijatuhkan bagi pelanggaran terhadap kewajiban: 
1. Setia dan taat sepenuhnya kepada Pancasila dan Undang-Undang Dasar Negara Republik Indonesia Tahun 1945, Negara Kesatuan Republik Indonesia, dan Pemerintah sebagaimana dimaksud dalam pasal 3 angka 3, apabila pelanggaran berdampak negatif pada pemerintah dan/atau negara.

2. Menaati segala ketentuan peraturan perundang-undangan sebagaimana dimaksud dalam pasal 3 angka 4, apabila pelanggaran berdampak negatif pada pemerintah dan/atau negara.

3. Melaksanakan tugas kedinasan yang dipercayakan kepada PNS dengan penuh pengabdian, kesadaran, dan tanggung jawab sebagaimana dimaksud dalam pasal 3 angka 5, apabila pelanggaran berdampak negatif pada pemerintah dan/atau negara.

4. Menjunjung tinggi kehormatan negara, pemerintah, dan martabat PNS sebagaimana dimaksud dalam pasal 3 angka 6, apabila pelanggaran berdampak negatif pada pemerintah dan/atau negara.

5. Mengutamakan kepentingan negara daripada kepentingan sendiri, seseorang, dan/atau golongan sebagaimana dimaksud dalam pasal 3 angka 7, apabila pelanggaran berdampak negatif pada pemerintah dan/atau negara.

6. Memegang rahasia jabatan yang menurut sifatnya atau menurut perintah harus dirahasiakan sebagaimana dimaksud dalam pasal 3 angka 8, apabila pelanggaran berdampak negatif pada pemerintah dan/atau negara.

7. Bekerja dengan jujur, tertib, cermat, dan bersemangat untuk kepentingan negara sebagaimana dimaksud dalam pasal 3 angka 9, apabila pelanggaran berdampak negatif pada pemerintah dan/atau negara.

8. Melaporkan dengan segera kepada atasannya apabila mengetahui ada hal yang dapat membahayakan atau merugikan negara atau Pemerintah terutama di bidang keamanan, keuangan, dan materiil sebagaimana dimaksud dalam pasal 3 angka 10 , apabila pelanggaran berdampak negatif pada pemerintah dan/atau negara.

9. Masuk kerja dan menaati ketentuan jam kerja sebagaimana dimaksud dalam pasal 3 angka 11 berupa:

a. penurunan pangkat setingkat lebih rendah selama 3 (tiga) tahun bagi PNS yang tidak masuk kerja tanpa alasan yang sah selama 31 (tiga puluh satu) sampai dengan 35 (tiga puluh lima) hari kerja;

b. pemindahan dalam rangka penurunan jabatan setingkat lebih rendah bagi PNS yang menduduki jabatan struktural atau fungsional tertentu yang tidak masuk kerja tanpa alasan yang sah selama 36 (tiga puluh enam) sampai dengan 40 (empat puluh) hari kerja;

c. pembebasan dari jabatan bagi PNS yang menduduki jabatan struktural atau fungsional tertentu yang tidak masuk kerja tanpa alasan yang sah selama 41 (empat puluh satu) sampai dengan 45 (empat puluh lima) hari kerja;

10. Mencapai sasaran kerja pegawai yang ditetapkan sebagaimana dimaksud dalam pasal 3 angka 12, apabila pencapaian sasaran kerja pegawai pada akhir tahun kurang dari $25 \%$ (dua puluh lima persen).

11. Menggunakan dan memelihara barangbarang milik negara dengan sebaik-baiknya sebagaimana dimaksud dalam pasal 3 angka 13, apabila pelanggaran berdampak negatif pada pemerintah dan/atau negara.

12. Memberikan pelayanan sebaik-baiknya kepada masyarakat sebagaimana dimaksud dalam pasal 3 angka 14 , sesuai dengan ketentuan peraturan perundang-undangan.

13. Menaati peraturan kedinasan yang ditetapkan oleh pejabat yang berwenang sebagaimana dimaksud dalam pasal 3 angka 17, apabila pelanggaran berdampak negatif pada pemerintah dan/atau negara.

Kewajiban yang diatur di atas harus dilaksanakan oleh semua Aparatur Sipil Negara. Termasuk yang berada pada lingkungan Lembaga Layanan Pendidikan Tinggi (LLDIKTI) Wilayah II. Lembaga Layanan Pendidikan Tinggi (LLDIKTI) Wilayah II adalah instansi pemerintah di lingkungan Kementerian Riset, Teknologi, dan Pendidikan Tinggi. Koordinasi Perguruan Tinggi Swasta (Kopertis) merupakan perpanjangan tangan Direktorat Jenderal Pendidikan Tinggi Kementerian Riset, Teknologi, dan Pendidikan Tinggi di suatu wilayah tertentu guna melaksanakan pengawasan, pengendalian, dan pembinaan terhadap perguruan tinggi swasta (PTS) di wilayah tersebut. Saat ini ada 12 Kopertis Wilayah di seluruh Indonesia. Kopertis Wilayah II Palembang merupakan salah satu dari 12 Kopertis Wilayah yang ada di Indonesia. 
Dari semua tugas yang diemban, ternyata tidak menjadikan pegawai yang ada di lingkungan Lembaga Layanan Pendidikan Tinggi (LLDIKTI) Wilayah II terlepas dari masalah-masalah kedisiplinan.

\section{LANDASAN TEORI}

\section{A. Pengertian Implementasi Kebijakan}

Menurut Webster's Dictionary, sebagaimana dikutip Wahab (2011: 187), implementasi dirumuskan sebagai "to implementation" (mengimplementasikan) yang berarti "to provide means for carrying out; to give practical effect to" (menyajikan alat bantu untuk melaksanakan; menimbulkan dampak/berakibat sesuatu).

Dalam studi kebijakan publik, dikatakan bahwa implementasi bukanlah sekadar bersangkut paut dengan mekanisme penjabaran keputusankeputusan politik ke dalam prosedur-prosedur rutin melalui saluran-saluran birokrasi, melainkan lebih dari itu implementasi menyangkut masalah konflik, keputusan, dan siapa yang memperoleh apa dari suatu kebijakan. Oleh karena itu, tidaklah terlalu salah jika dikatakan bahwa implementasi kebijakan merupakan aspek yang sangat penting dalam keseluruhan proses kebijakan.

Pengertian yang sangat sederhana tentang implementasi diungkapkan oleh Riant Nugroho (2014: 163), yakni "getting the job done" dan "doing $i t$ ". Kesederhanaan rumusan implementasi kebijakan ini merupakan suatu proses atau strategi yang dapat dilakukan dengan mudah. Sebagai proses penerimaan sumber daya tambahan, batasan implementasi mempertimbangkan apa yang harus dilakukan.

Van Meter dan van Horn (Wahab, 2011: 65) mendefinisikan implementasi kebijakan sebagai berikut: "Policy implementation encompasses those actions by public and private individuals (and groups) that are directed at the achievement of goals and objectives set forth in prior policy decisions." Definisi ini bermakna bahwa implementasi kebijakan merupakan tindakan-tindakan yang dilakukan oleh individu-individu (dan kelompok) pemerintah dan swasta yang diarahkan pada pencapaian tujuan dan sasaran yang telah ditetapkan. Tindakan-tindakan ini-pada suatu saat-berusaha untuk mentransformasikan keputusan-keputusan menjadi pola-pola operasional, serta melanjutkan usaha-usaha tersebut untuk mencapai perubahan, baik yang besar maupun yang kecil, yang diamanatkan oleh keputusan kebijakan. Menurut Wahab (2011: 272), agar dapat dilaksanakan dengan baik, kebijakan hendaknya:

1. Dirancang sesuai dengan kerangka acuan dan teori yang kuat.

2. Disusun korelasi yang jelas antara kebijakan dan implementasinya.

3. Ditetapkan adanya organisasi yang mengoordinasikan pelaksanaan kebijakan sehingga proses implementasi dapat berjalan dengan baik.

4. Dilakukan sosialisasi kebijakan yang akan diterapkan sampai organisasi pelaksana tingkat terbawah (street level bureaucracy).

5. Dilakukan pemantauan terus-menerus (monitoring).

6. Diberi bobot yang sama penting antara kebijakan dan implementasinya. Maksudnya, pembuat kebijakan harus menilai sama penting antara kebijakan dan implementasinya sehingga antara kebijakan dan implementasinya tidak terjadi kesenjangan yang menyulitkan pelaksanaan.

Dengan demikian, proses (implementasi) kebijakan baru akan dimulai apabila tujuan-tujuan kebijakan telah ditetapkan, program pelaksanaan telah dibuat, sumber daya kebijakan (seperti dana, sarana dan prasarana pendukung) telah disediakan, sumber daya manusia (pelaku/agen kebijakan), serta alat kontrol pelaksanaan kebijakan telah ditetapkan dan dialokasikan untuk mencapai tujuan. Untuk mengefektifkan implementasi kebijakan yang ditetapkan, diperlukan adanya tahap-tahap implementasi kebijakan.

Sukses ataupun gagalnya suatu kebijakan atau implementasi dipengaruhi oleh seberapa besar dukungan terhadap kebijakan tersebut, adanya sumber daya, serta pemahaman dan kepatuhan dari para pelaku kebijakan. Sehubungan dengan hal itu sosialisasi kebijakan, sinergi kegiatan/proses dari para pelaku kebijakan dan monitoring pelaksanaan kebijakan akan menjadi penting dalam implementasi kebijakan. Diperlukan kerangka untuk memantau itu semua, yaitu melalui suatu model implementasi.

Dengan mengacu pada penjelasan di atas, dapat diambil pengertian bahwa sumber-sumber mencapai tujuan yang telah ditetapkan sebelumnya oleh pembuat kebijakan mencakup: manusia, dana, dan kemampuan organisasi, yang dilakukan baik oleh pemerintah maupun swasta (individu ataupun kelompok). 
Mazmanian dan Sabatier (dalam Wahab, 2011: 68) menjelaskan lebih lanjut tentang konsep implementasi kebijakan: "Memahami apa yang senyatanya terjadi sesudah program dinyatakan berlaku atau dirumuskan merupakan fokus perhatian implementasi kebijakan, yaitu kejadiankejadian atau kegiatan yang timbul setelah disahkannya pedoman-pedoman kebijakan negara, yang mencakup baik usaha-usaha untuk mengadministrasikannya maupun untuk menimbulkan akibat/dampak nyata pada masyarakat atau kejadian-kejadian.”

Berdasarkan pendapat di atas, tampak bahwa implementasi kebijakan tidak hanya terbatas pada tindakan atau perilaku badan alternatif atau unit birokrasi yang bertanggung jawab untuk melaksanakan program dan menimbulkan kepatuhan dari kelompok sasaran (target group), namun lebih dari itu juga berlanjut dengan jaringan kekuatan politik sosial ekonomi yang berpengaruh pada perilaku semua pihak yang terlibat hingga pada akhirnya terdapat dampak yang diharapkan maupun yang tidak diharapkan.

\section{B. Model Implementasi}

Dalam rangka memecahkan masalah ada beberapa tahap penting dari kebijakan publik, antara lain menurut William N. Dunn (dalam Keban, 2014: 62) yaitu: penetapan agenda kebijakan (agenda setting), formulasi kebijakan (policy formulation), adopsi kebijakan (policy adoption), implementasi kebijakan (policy implementation), dan penilaian kebijakan (policy assessment). Dalam kenyataannya, betapapun hebatnya suatu kebijakan/rencana yang dibuat tidak akan ada gunanya jika tidak direalisasikan dengan baik dan benar. Oleh karena itu, tahap implementasi merupakan tahap yang paling penting sehingga model implementasi kebijakan pun menjadi penting untuk diketahui. Berikut beberapa model implementasi kebijakan.

Menurut Keban (2014: 63), pada prinsipnya terdapat dua pemilahan model implementasi kebijakan, yaitu yang pertama, implementasi kebijakan yang berpola "dari atas ke bawah" (topbottomer) dan dari "bawah ke atas" (bottom-topper); dan kedua, implementasi yang berpola paksa (command-and-control) dan mekanisme pasar (economic incentive). Model mekanisme paksa adalah model yang mengedepankan arti penting lembaga publik sebagai lembaga tunggal yang mempunyai monopoli atas mekanisme paksa di dalam negara dengan tidak ada mekanisme insentif bagi yang menjalani tapi memberlakukan sanksi bagi yang menolak melaksanakan atau melanggarnya. Model mekanisme pasar adalah model yang mengedepankan mekanisme insentif bagi yang menjalani, dan bagi yang tidak menjalankan tidak mendapatkan sanksi dan tidak juga mendapatkan insentif. Model "top-down" berupa pola yang dikerjakan oleh pemerintah untuk rakyat, dengan partisipasi lebih berbentuk mobilisasi. Sebaliknya "bottom-up" bermakna bahwa meski kebijakan dibuat oleh pemerintah, pelaksanaannya dilakukan oleh rakyat. Di antara kedua kutub ini ada interaksi pelaksanaan antara pemerintah dan masyarakat.

Berikut ini beberapa model implementasi dari beberapa tokoh yang dikutip dari Nugroho (2014: 165).

\section{Model Implementasi Donald van Meter dengan Carl van Horn}

Model kebijakan ini berpola "puncak ke bawah" dan lebih kepada "mekanisme paksa" daripada "mekanisme pasar". Model kebijakan ini mengandaikan bahwa implementasi kebijakan berjalan secara linier daripada kebijakan publik, implementor, dan kinerja kebijakan publik. Dalam model implementasi kebijakan ini terdapat empat variabel yang membentuk hubungan antara kebijakan dengan pelaksanaan. Van Meter dan van Horn dalam teorinya ini beranjak dari argumen bahwa perbedaan-perbedaan dalam proses implementasi akan dipengaruhi oleh sifat kebijakan yang akan dilaksanakan. Mereka menawarkan suatu pendekatan yang mencoba untuk menghubungkan antara isu kebijakan dengan implementasi dan suatu model konseptual yang menghubungkan dengan prestasi kerja (performance). Kedua ahli ini menegaskan pula pendiriannya bahwa perubahan, kontrol, dan kepatuhan bertindak merupakan konsep-konsep penting dalam prosedur implementasi. Beberapa variabel yang dimasukkan sebagai variabel yang mempengaruhi kebijakan publik adalah:

1) Aktivitas implementasi dan komunikasi antar-organisasi.

2) Karakteristik dari agen pelaksana/implementor.

3) Kondisi ekonomi, sosial, dan politik.

4) Kecenderungan dari pelaksana/implementor. 
Gambar 1. Model Implementasi dari Donald van Meter dengan Carl van Horn (1975)

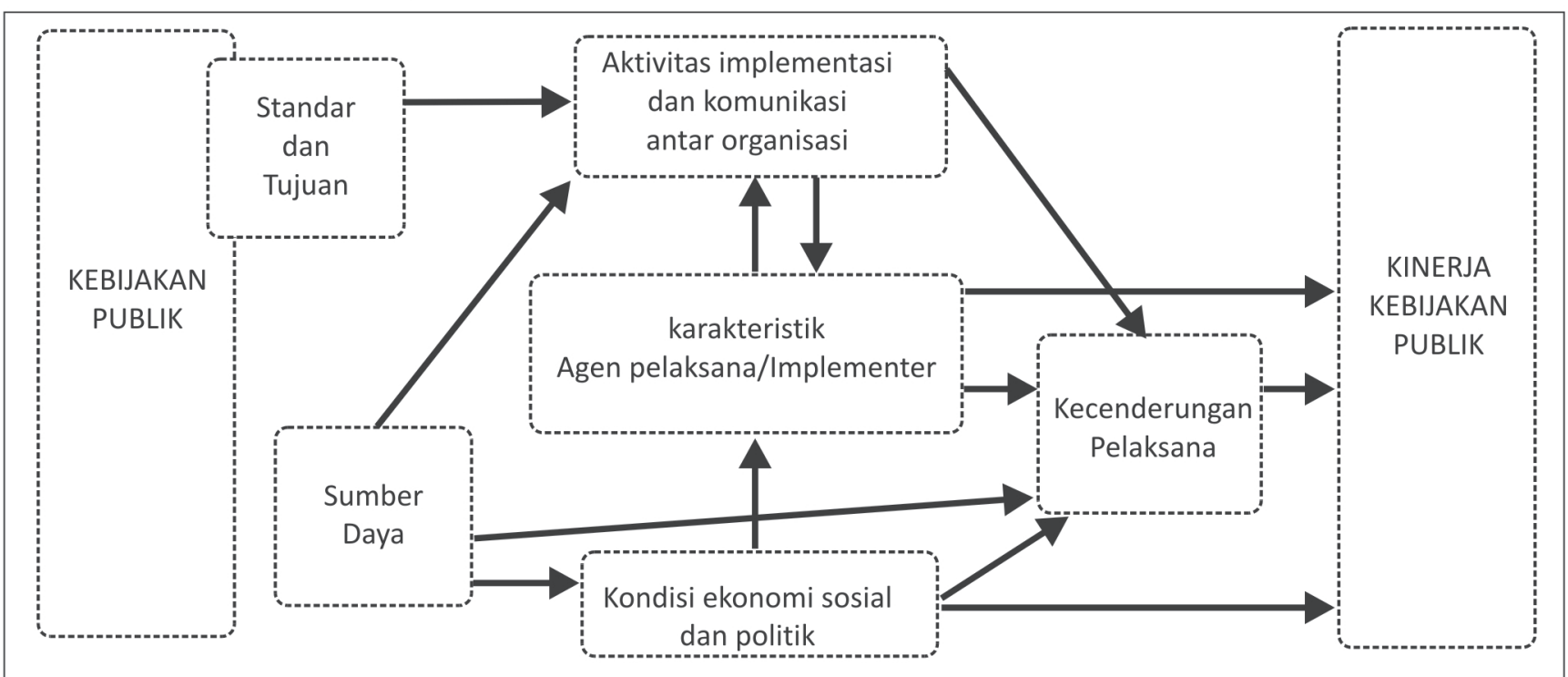

Sumber: Nugroho (2003:165)

Berdasarkan gambar di atas, dapat dijelaskan bahwa perbedaan-perbedaan dalam implementasi akan dipengaruhi oleh sifat kebijakan yang meliputi: aktivitas implementasi dan komunikasi antarorganisasi, karakteristik agen pelaksana/implementor, kondisi ekonomi, sosial, dan politik, serta kecenderungan pelaksana/implementor. Suatu standar, tujuan, dan sumber daya serta sifat kebijakan sebagai variabel yang mempengaruhi kebijakan dihubungkan ke dalam suatu model konseptual (implementasi) yang mempertalikan kebijakan dengan kinerja kebijakan.

Proses implementasi ini akan dipengaruhi oleh dimensi-dimensi kebijakan semacam itu. Artinya, kebanyakan implementasi akan berhasil apabila perubahan yang dikehendaki relatif sedikit. Saat yang sama, kesepakatan terhadap tujuan-terutama dari mereka yang mengoperasikan program di lapangan-relatif tinggi.

Standar dan tujuan kebijakan mempunyai pengaruh tidak langsung terhadap pelaksanaan atau penyelenggaraan kebijakan. Selain itu, standar dan tujuan kebijakan juga berpengaruh tidak langsung terhadap disposisi para pelaksana melalui aktivitas komunikasi antar-organisasi. Kejelasan respons para pelaksana terhadap suatu kebijakan didasarkan pada persepsi dan interpretasi mereka terhadap tujuan kebijakan tersebut. Walaupun demikian, hal ini bukan berarti komunikasi yang baik akan menyeimbangkan disposisi yang baik atau positif di antara para pelaksana. Standar dan tujuan juga mempunyai dampak yang tidak langsung terhadap disposisi para pelaksana melalui aktivitas penguatan atau pengabsahan. Dalam hal ini para atasan dapat meneruskan hubungan para pelaksana dengan organisasi lain.

Hubungan antara sumber daya (resources) dengan kondisi sosial, ekonomi, dan politik dalam batas wilayah organisasi tertentu dapat dikemukakan bahwa tersedianya dana dan sumber lain dapat menimbulkan tuntutan dari warga masyarakat swasta, kelompok kepentingan yang terorganisasi untuk ikut berperan dalam melaksanakan dan menyukseskan suatu kebijakan. Jelasnya prospek keuntungan dapat menyebabkan kelompok lain untuk berperan serta secara maksimal dalam melaksanakan dan menyukseskan suatu program kebijakan.

Bagaimanapun juga, dengan terbatasnya sumber daya yang tersedia, masyarakat suatu negara secara individual dan kelompok kepentingan yang terorganisasi akan memilih untuk menolak suatu kebijakan karena keuntungan yang diperolehnya lebih kecil bila dibandingkan biaya operasional. Demikian juga kondisi sosial, ekonomi, dan politik dalam batas wilayah tertentu, yang mempengaruhi karakter-karakter agen-agen pihak pelaksana, disposisi para pelaksana dan penyelenggaraan atau pelaksanaan kebijakan itu sendiri.

Kondisi lingkungan di atas mempunyai efek penting terhadap kemauan dan kapasitas untuk mendukung struktur birokrasi yang mapan, berkualitas, dan sebagai agen pelaksana (implementor). Kondisi lapangan ini juga mempengaruhi disposisi implementor. Suatu program kebijakan akan didukung dan digerakkan oleh para warga pihak swasta, kelompok kepentingan yang terorganisasi, hanya jika para 
implementor mau menerima tujuan, standar, dan sasaran kebijakan tersebut. Sebaliknya, suatu kebijakan tidak akan mendapat dukungan jika kebijakan tersebut tidak memberikan keuntungan kepada mereka.

Selain itu, karakteristik para agen implementor dapat mempengaruhi disposisi mereka. Sifat jaringan komunikasi, derajat kontrol secara berjenjang, dan tipe kepemimpinan dapat mempengaruhi identifikasi individual terhadap tujuan dan sasaran organisasi. Implementasi kebijakan yang efektif sangat bergantung pada orientasi para agen/kantor implementor kebijakan.

Berdasarkan uraian di atas dapat dipahami bahwa keberhasilan implementasi kebijakan sangat dipengaruhi oleh berbagai variabel atau faktor yang pada gilirannya akan mempengaruhi keberhasilan implementasi kebijakan itu sendiri.

\section{Model Kerangka Analisis Implementasi}

(Framework for Implementation Analysis) dari Daniel Mazmanian dan Paul A. Sebatier.

Model implementasi kebijakan ini berada pada kuadran "puncak ke bawah" dan lebih berada di "mekanisme paksa" daripada "mekanisme pasar". Kedua tokoh ini mengklasifikasikan proses implementasi kebijakan ke dalam tiga variabel.

1) Variabel independen, yaitu mudah tidaknya masalah dikendalikan yang berkenaan dengan indikator masalah teori dan teknis pelaksanaan, keragaman objek, dan perubahan yang dikehendaki.

2) Variabel intervening, yaitu variabel kemampuan kebijakan untuk menstrukturkan proses implementasi dengan indikator kejelasan dan konsistensi tujuan, dipergunakannya teori kausal, ketepatan alokasi sumber dana, keterpaduan hierarkis di antara lembaga pelaksana, aturan pelaksana dari lembaga pelaksana, dan perekrutan pejabat pelaksana dan keterbukaan kepada pihak luar; selanjutnya, variabel di luar kebijakan yang mempengaruhi proses implementasi yang berkenaan dengan indikator kondisi sosioekonomi dan teknologi, dukungan publik, sikap risorsis dari konstituen, dukungan pejabat yang lebih tinggi, serta komitmen dan kualitas kepemimpinan dari pejabat pelaksana.

3) Variabel dependen, yaitu tahapan dalam proses implementasi dengan lima tahapan, yaitu pemahaman dari lembaga/badan pelaksana dalam bentuk disusunnya kebijakan pelaksana, kepatuhan objek, hasil nyata, penerimaan atas hasil nyata tersebut, dan akhirnya mengarah kepada revisi atas kebijakan yang dibuat dan dilaksanakan tersebut ataupun keseluruhan kebijakan yang bersifat mendasar.

Proses implementasi kebijakan tidak terlepas dari faktor atau variabel yang mempengaruhi tercapainya tujuan proses implementasi, yaitu mudah tidaknya masalah dikendalikan, kemampuan kebijakan menstrukturkan proses implementasi, dan pengaruh faktor luar kebijakan. Semuanya berpengaruh pada proses implementasi yang dimulai dengan dihasilkannya keluaran (output) kebijakan dari organisasi, kemudian menuju kepada kesediaan kelompok sasaran mematuhi output kebijakan. Setelah itu, dihasilkan dampak nyata berupa output kebijakan yang hasilnya terlihat melalui perbaikan mendasar terhadap peraturan yang telah atau belum dilaksanakan, yang berguna untuk menilai kinerja implementasi kebijakan untuk selanjutnya dapat diputuskan untuk direvisi atau tidak.

\section{Model Implementasi Kebijakan dari Brian W. Hogwood dan Lewis A. Gun.}

Model ini berada pada mekanisme paksa sekaligus pada mekanisme pasar. Menurut kedua pakar ini, untuk melaksanakan implementasi kebijakan diperlukan beberapa syarat, yaitu:

1) Adanya jaminan bahwa kondisi eksternal yang dihadapi oleh lembaga/badan pelaksana tidak akan menimbulkan masalah besar.

2) Tersedia sumber daya yang memadai, termasuk sumber daya waktu. Syarat ini berkenaan dengan feasibilitas dari implementasi kebijakan.

3) Perpaduan sumber-sumber yang diperlukan benar-benar ada. Kebijakan publik adalah kebijakan yang kompleks dan menyangkut dampak yang luas. karena itu, implementasi kebijakan publik akan melibatkan berbagai sumber yang diperlukan, baik dalam konteks sumber daya ataupun sumber-sumber aktor.

4) Kebijakan yang akan diimplementasikan didasari hubungan kausal yang andal. Secara prinsip, apakah kebijakan tersebut memang dapat menyelesaikan masalah yang ditanggulangi ataukah tidak.

5) Seberapa banyak hubungan kausalitas yang terjadi. Asumsinya adalah semakin sedikit hubungan sebab-akibat, maka semakin tinggi 
pula hasil yang dikehendaki oleh kebijakan tersebut dapat dicapai. Sebuah kebijakan yang mempunyai hubungan kausalitas yang kompleks, otomatis menurunkan efektivitas implementasi kebijakan.

6) Hubungan saling ketergantungan kecil. Asumsinya adalah jika hubungan saling ketergantungan tinggi, justru implementasi tidak dapat berjalan secara efektif apalagi jika hubungannya adalah ketergantungan.

7) Pemahaman yang mendalam dan kesepakatan terhadap tujuan.

8) Tugas-tugas telah dirinci dan ditempatkan dalam urutan yang benar. Tugas yang jelas dan prioritas yang jelas adalah kunci efektivitas implementasi kebijakan.

9) Komunikasi dan koordinasi yang sempurna. Komunikasi adalah perekat organisasi, dan koordinasi adalah asal muasal dari kerja sama tim serta terbentuknya sinergi.

10) Pihak-pihak yang memiliki wewenang kekuasaan dapat menuntut dan mendapatkan kepatuhan yang sempurna. Kekuasaan adalah syarat bagi efektivitas implementasi kebijakan. Tanpa otoritas yang berasal dari kekuasaan, maka kebijakan akan tetap berupa kebijakan tanpa ada dampak bagi target kebijakan.

Model Hogwood dan Gunn mendasarkan pada konsep manajemen strategis yang mengarah pada praktik manajemen yang sistematis dan tidak meninggalkan kaidah-kaidah pokok kebijakan publik. Kelemahan konsep ini adalah tidak secara tegas mana yang bersifat politis, strategis, dan teknis atau operasional.

\section{Model Merilee S. Grindle}

Grindle (2000: 12) memprediksikan bahwa dalam setiap implementasi kebijakan pemerintah pasti dihadapkan pada banyak kendala, terutama yang berasal dari lingkungan (konteks) tempat kebijakan itu akan diimplementasikan. Ide dasar Grindle ini adalah setelah suatu kebijakan ditransformasikan menjadi program aksi, maka tindakan implementasi belum tentu berlangsung lancar. Hal ini sangat bergantung pada implementabilitas dari program/kebijakan tersebut. Keberhasilannya ditentukan oleh derajat implementabilitas dari kebijakan tersebut, yaitu bagaimana konten (isi) dan konteks kebijakan tersebut. Isi kebijakan mencakup:

1) Kepentingan yang terpengaruh oleh kebijakan.
2) Jenis manfaat yang akan dihasilkan.

3) Derajat perubahan yang diinginkan.

4) Kedudukan pembuat kebijakan.

5) (Siapa) pelaksana program.

6) Sumber daya yang dikerahkan.

Sementara itu konteks implementasinya adalah:

1) Kekuasaan, kepentingan, dan strategi aktor yang terlibat.

2) Karakteristik lembaga dan penguasa.

3) Kepatuhan dan daya tanggap.

Hasil Kebijakan:

1) Dampak pada masyarakat, baik individu maupun kelompok.

2) Perubahan dan penerimaan oleh masyarakat.

Model kebijakan Grindle dapat digambarkan dalam bentuk bagan berikut. 


\section{Model Implementasi Kebijakan Menurut Grindle}

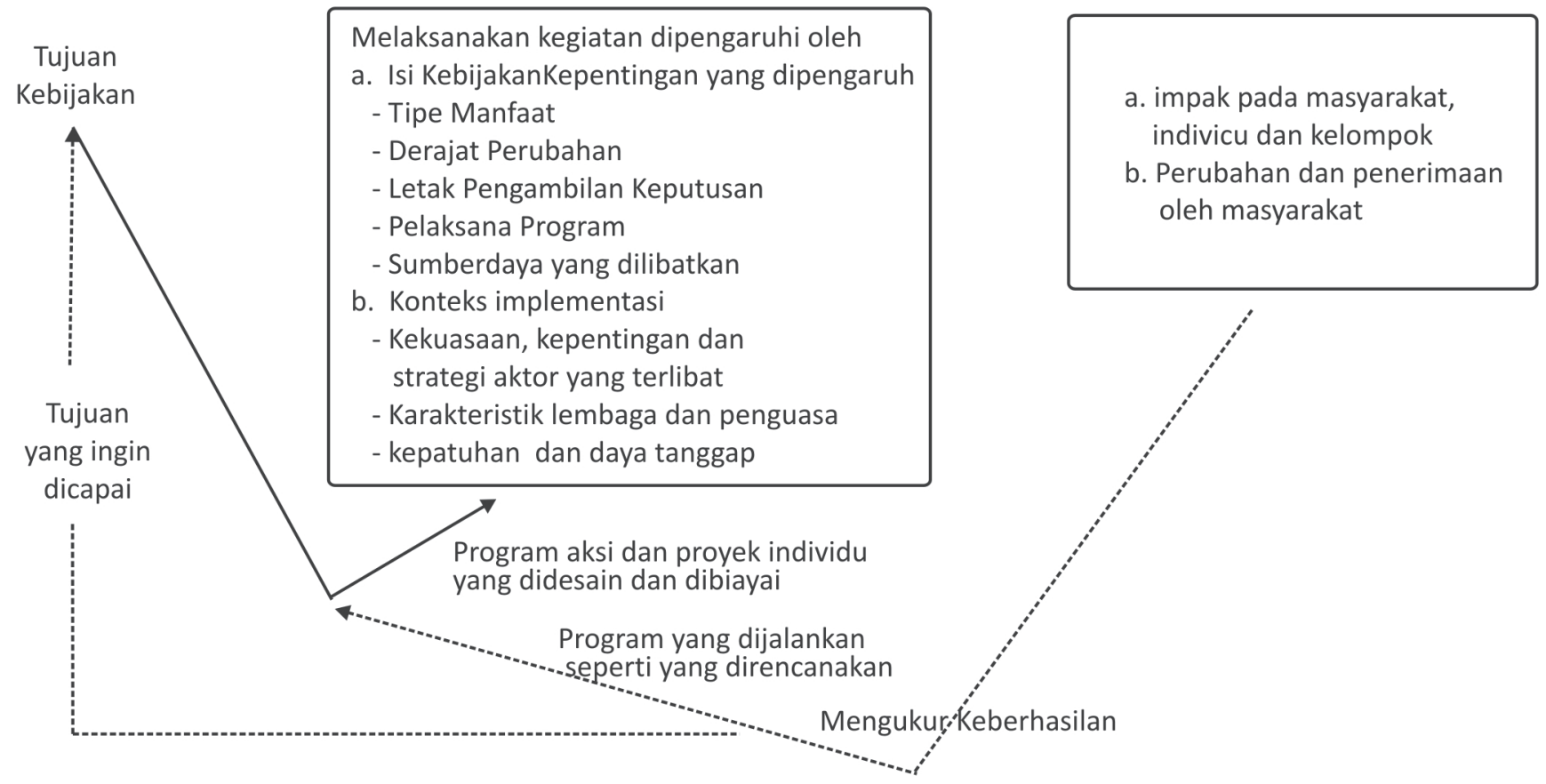

Sumber: Syahruddin (2009)

Keberhasilan implementasi kebijakan diukur dengan melihat gap (kesenjangan) antara tujuan yang ingin dicapai dengan hasil yang dicapai melalui pelaksanaan program aksi atau proyek yang dijalankan. Artinya, apakah hasil yang dicapai sesuai dengan tujuan atau hasil yang direncanakan ataukah tidak. Sementara itu, tujuan yang ingin dicapai akan dipengaruhi oleh isi kebijakan dan konteks implementasi sehingga keberhasilan atau kegagalan dalam implementasi dapat dideteksi dari konten dan konteks kebijakan.

Model tersebut menggambarkan proses pengambilan keputusan yang dilakukan oleh beragam aktor, dengan keluaran akhir ditentukan oleh materi program yang telah dicapai dan interaksi para pembuat keputusan dalam konteks politik administratif. Proses politik dapat terlihat melalui proses pengambilan keputusan yang melibatkan berbagai aktor kebijakan, sedangkan proses administrasi terlihat melalui proses umum mengenai aksi administratif yang dapat diteliti pada tingkat program tertentu.

Model Implementasi kebijakan yang digunakan dalam penelitian ini adalah model implementasi dari George C. Edward III.

Menurut George C. Edward III (2002:168) ada empat faktor yang berpengaruh terhadap keberhasilan atau kegagalan implementasi suatu kebijakan, yaitu faktor sumber daya, birokrasi, komunikasi, dan disposisi.

\section{Faktor sumber daya (resources)}

Faktor sumber daya mempunyai peranan penting dalam implementasi kebijakan karena bagaimanapun juga jelas dan konsisten ketentuanketentuan atau aturan-aturan suatu kebijakan. Jika para personel yang bertanggung jawab mengimplementasikan kebijakan kurang mempunyai sumber-sumber untuk melakukan pekerjaan secara efektif, maka implementasi kebijakan tersebut tidak akan bisa efektif. Sumber-sumber penting dalam implementasi kebijakan yang dimaksud antara lain mencakup:

a) Staf yang harus mempunyai keahlian dan kemampuan untuk bisa melaksanakan tugas;

b) Perintah;

c) Anjuran atasan/pimpinan

Selain itu, harus ada ketepatan atau kelayakan antara jumlah staf yang dibutuhkan dan keahlian yang dimiliki dengan tugas yang akan dikerjakan.

Dana dipergunakan untuk membiayai operasionalisasi implementasi kebijakan tersebut. Informasi yang relevan mencukupi dalam hal bagaimana mengimplementasikan suatu kebijakan. Demikian juga kerelaan atau kesanggupan dari berbagai pihak yang terlibat dalam implementasi kebijakan tersebut. Hal ini dimaksudkan agar para implementor tidak akan melakukan suatu kesalahan dalam mengimplementasikan kebijakan tersebut. 
Informasi yang demikian ini penting untuk menyadarkan orang-orang yang terlibat dalam implementasi agar di antara mereka melaksanakan dan mematuhi apa yang menjadi tugas dan kewajibannya.

Kewenangan diperlukan untuk menjamin atau meyakinkan bahwa kebijakan yang diimplementasikan sesuai dengan tujuan yang dikehendaki. Fasilitas yang digunakan untuk mengoperasionalkan implementasi suatu kebijakan meliputi: gedung, tanah, sarana dan prasarana yang kesemuanya akan memberikan pelayanan dalam implementasi kebijakan. Kurang cukupnya sumbersumber ini berarti tidak bakal kuatnya ketentuanketentuan atau aturan-aturan sehingga pelayanan tidak akan diberikan dan pengaturan yang rasional tidak dapat dikembangkan.

\section{Struktur birokrasi}

Meskipun sumber-sumber untuk mengimplementasikan suatu kebijakan sudah mencukupi dan para implementor mengetahui apa dan bagaimana cara melakukannya, serta mereka mempunyai keinginan untuk melakukannya, implementasi bisa jadi masih belum efektif karena ketidakefisienan struktur birokrasi yang ada.

\section{Komunikasi}

Komunikasi adalah suatu kegiatan manusia untuk menyampaikan apa yang menjadi pemikiran dan perasaannya, harapan atau pengalamannya kepada orang lain Menurut teori George C. Edward III, faktor komunikasi dianggap sebagai faktor yang amat penting karena dalam setiap proses kegiatan yang melibatkan unsur manusia dan sumber daya akan selalu berurusan dengan permasalahan "bagaimana hubungan yang dilakukan" (Nugroho, 2003: 201).

4. Disposisi (sikap)

Kecenderungan perilaku atau karakteristik pelaksana kebijakan berperan penting dalam mewujudkan implementasi kebijakan yang sesuai dengan tujuan atau sasaran. Karakter penting yang harus dimiliki oleh pelaksana kebijakan misalnya adalah kejujuran dan komitmen yang tinggi. Kejujuran mengarahkan implementor untuk tetap berada dalam capaian program yang telah digariskan, sedangkan komitmen yang tinggi dari pelaksana kebijakan akan membuat mereka selalu antusias dalam melaksanakan tugas, wewenang, fungsi, dan tanggung jawab sesuai dengan peraturan yang ditetapkan.

\section{Pengertian Disiplin Kerja}

Disiplin dapat diartikan sebagai "ketaatan terhadap peraturan, atau tata tertib yang berlaku pada suatu organisasi, instansi atau lingkungan tempat seseorang berada atau menjadi anggota dalam lingkungan tersebut". Sementara itu kerja dapat diartikan sebagai "melakukan suatu kegiatan atau aktivitas". Berdasarkan makna tersebut, disiplin kerja dapat didefinisikan sebagai "ketaatan terhadap peraturan dan atau tata tertib yang berlaku di tempat seseorang melakukan kegiatan atau pekerjaannya yang biasanya bersifat mengikat." Dalam Peraturan Pemerintah Nomor 53 tahun 2010 tentang Disiplin Pegawai Negeri Sipil, dijelaskan yang dimaksud dengan Disiplin Pegawai Negeri Sipil adalah kesanggupan Pegawai Negeri Sipil untuk menaati kewajiban dan menghindari larangan yang ditentukan dalam peraturan pemerintah, perundangundangan, atau peraturan kedinasan yang apabila tidak ditaati atau dilanggar maka dijatuhi hukuman disiplin.

Disiplin kerja menurut Sinungan adalah "sikap mental yang tercermin dalam perbuatan atau tingkah laku individu, kelompok, atau masyarakat berupa ketaatan terhadap peraturan-peraturan atau ketentuan yang ditetapkan untuk tujuan tertentu." Sinungan juga mengemukakan bahwa disiplin kerja adalah "kesanggupan seorang pegawai negeri sipil untuk menaati segala peraturan perundangundangan dan peraturan kedinasan yang berlaku, menaati perintah kedinasan yang diberikan oleh atasan yang berwenang, serta kesanggupan untuk tidak melanggar larangan yang ditentukan" (dalam Manihuruk, 1995: 12).

Menurut Henry Simamora (2004: 610), disiplin adalah prosedur yang mengoreksi atau menghukum bawahan karena melanggar peraturan atau prosedur. Disiplin merupakan pengendalian diri pegawai dan pelaksanaan yang teratur, dan menunjukkan tingkat kesungguhan tim kerja di sebuah organisasi. Tindakan disipliner menuntut suatu hukuman terhadap karyawan yang gagal memenuhi standar yang ditetapkan

$$
\text { Menurut Merriam-Webster's Collegiate }
$$

Dictionary (dalam Prijono 2005: 3) pengertian disiplin yang berasal dari kata dalam bahasa Inggris discipline sebagai a rule or system of rules governing or activity (peraturan atau tata aturan yang mengarahkan perilaku atau kegiatan). Disiplin kerja merupakan komponen yang turut menentukan baik buruknya kinerja seseorang. Seseorang pegawai yang disiplin dalam bekerja akan cenderung untuk 
melakukan segala aktivitasnya sesuai dengan tata aturan, standar maupun tugas dan tanggung jawab yang menjadi tanggung jawabnya. Seseorang pegawai yang sering datang terlambat secara otomatis merugikan instansi tempatnya bekerja.

Menurut Poerwadarminta (1987: 127), pembinaan adalah suatu usaha, tindakan, dan kegiatan yang dilakukan guna memperoleh hasil yang lebih baik.

Menurut Widjaja (1988: 92), pembinaan adalah suatu proses atau pengembangan yang mencakup urutan-urutan pengertian; diawali dengan mendirikan, membutuhkan, memelihara pertumbuhan tersebut yang disertai usaha-usaha perbaikan, menyempurnakan, dan mengembangkannya. Pembinaan tersebut menyangkut kegiatan perencanaan, pengorganisasian, pembiayaan, koordinasi, pelaksanaan, dan pengawasan suatu pekerjaan untuk mencapai tujuan hasil yang maksimal.

\section{Tujuan Penegakan Disiplin Kerja}

Penegakan disiplin kerja pada intinya dimaksudkan agar terjadi keselarasan antara tata aturan atau standar yang telah ditetapkan oleh pihak manajemen dan perilaku para pegawai dalam lingkungan kerja mereka.

Handoko (2002: 276) menyebutkan tiga macam penegakan disiplin kerja, yaitu:

1. Disiplin preventif, yaitu kegiatan yang dilaksanakan untuk mendorong para karyawan agar mengikuti berbagai standar atau aturan sehingga penyelewengan-penyelewengan dapat dicegah.

2. Disiplin korektif, yaitu kegiatan yang diambil untuk menangani pelanggaran-pelanggaran terhadap aturan yang ditetapkan. Kegiatan korektif sering kali berupa pemberian hukuman atau sanksi. Tujuannya adalah untuk memperbaiki kegiatan pada waktu akan datang, bukan menghukum kegiatan pada masa lalu.

3. Disiplin progresif, yaitu suatu kebijaksanaan dengan memberikan hukuman-hukuman yang lebih berat terhadap pelanggaran-pelanggaran yang berulang. Tujuannya adalah memberi kesempatan kepada pegawai untuk mengambil tindakan korektif sebelum hukuman-hukuman yang lebih serius dilaksanakan.

Dalam pasal 1 ayat (3) Peraturan Pemerintah Republik Indonesia Nomor 53 Tahun 2010 tentang Disiplin Kerja Pegawai Negeri Sipil dijelaskan bahwa yang dimaksud dengan Pelanggaran Disiplin adalah setiap ucapan, tulisan, atau perbuatan PNS yang tidak menaati kewajiban atau melanggar larangan Ketentuan Disiplin Pegawai Negeri Sipil, baik yang dilakukan di dalam maupun di luar jam kerja. Untuk menghindari adanya pelanggaran terhadap ketentuan yang ada, maka diperlukan adanya hukuman dan sanksi. Hukuman dalam peningkatan kedisiplinan merupakan alat untuk menindak pegawai agar mau dan menaati peraturan yang ada. Tingkat dan jenis hukuman disiplin jika seseorang Pegawai Negeri Sipil melakukan pelanggaran dijelaskan pada pasal 7 peraturan tersebut:

(1) Tingkat hukuman disiplin terdiri dari:
a. Hukuman disiplin ringan;
b. Hukuman disiplin sedang;
c. Hukuman disiplin berat;

(2) Jenis hukuman disiplin ringan sebagaimana dimaksud pada ayat (1) huruf a

terdiri dari:
a. Teguran lisan;
b. Teguran tertulis;
c. Pernyataan tidak puas secara tertulis.

(3) Jenis hukuman disiplin sedang sebagaimana dapat dimaksud pada ayat (1)

huruf $b$ terdiri dari:
a. Penundaan kenaikan gaji berkala selama satu tahun;
b. Penundaan kenaikan pangkat selama 1 tahun;
c. Penurunan pangkat setingkat lebih rendah selama 1 tahun.

(4) Jenis hukuman disiplin berat sebagaimana dimaksud pada ayat (1) huruf $\mathrm{c}$ terdiri dari:
a. Penurunan pangkat setingkat lebih rendah selama 3 tahun;
b. Pemindahan dalam rangka penurunan jabatan setingkat lebih rendah;
c. Pembebasan dari jabatan;
d. Pemberhentian dengan hormat tidak atas permintaan sendiri sebagai PNS;
e. Pemberhentian tidak dengan hormat sebagai PNS.

Jika seorang pegawai melakukan tindakan tidak disiplin, selain adanya penegakan disiplin secara tegas dalam bentuk hukuman, diperlukan juga tindakan persuasif untuk mencari tahu faktor-faktor yang menyebabkan terjadinya perilaku indisipliner tersebut. Dengan diketahuinya faktor-faktor penyebab tersebut, diharapkan pelanggaran yang sama tidak akan terjadi lagi pada masa mendatang.

Menurut Handoko (2002: 278), dilakukannya pembinaan disiplin kerja bertujuan untuk: 
a. Agar semua pegawai yang ada di kantor berperilaku bijaksana di tempat kerja, dalam arti taat kepada peraturan dan keputusan. Melayani tujuan yang sama seperti yang dilakukan undang-undang di masyarakat.

b. Untuk menjamin adanya kesamaan antara tujuan kantor dengan tujuan masing-masing para pegawai.

c. Untuk menciptakan situasi yang bagus dalam mencapai tujuan dari pekerjaan sehingga kinerja pegawai meningkat, yang pada akhirnya kinerja kantor pun meningkat.

\section{E. Indikator Disiplin Pegawai}

Para pegawai seharusnya memahami indikator-indikator yang mempengaruhi tingkat kedisiplinan pada suatu perusahaan. Indikator tersebut adalah sebagai berikut (Hasibuan, 2003: 214):

\section{a. Tujuan dan kemampuan}

Tujuan yang ingin dicapai harus jelas dan ditetapkan secara ideal sehingga cukup menantang kemampuan pegawai. Hal ini berarti tujuan yang dibebankan kepada pegawai harus sesuai dengan kemampuannya sehingga pegawai tersebut melakukannya dengan segenap kemampuan.

b. Teladan pimpinan

Keteladanan seseorang pemimpin sangat berperan dalam menentukan kedisiplinan pegawai karena pimpinan dijadikan teladan dan panutan oleh para bawahan. Pimpinan harus memberikan contoh yang baik, berdisiplin baik, jujur, adil, dan sesuai antara kata dan perbuatan.

c. Kesejabteraan

Kesejahteraan pegawai memiliki pengaruh besar terhadap kedisiplinan pegawai. Hal ini disebabkan karena hal tersebut akan menimbulkan kepuasan dan kecintaan pegawai terhadap pekerjaannya.

d. Ancaman

Ancaman perlu ditegakkan dalam batas-batas yang tidak melanggar peraturan yang berlaku, baik internal (instansi atau perusahaan) maupun eksternal (peraturan pemerintah atau perundang-undangan), untuk memelihara kedisiplinan pegawai. Jika hukuman yang diberikan semakin berat, maka pegawai takut untuk melanggar

\begin{abstract}
peraturan-peraturan perusahaan.
e. Ketegasan

Ketegasan pimpinan dalam melakukan tindakan akan mempengaruhi kedisiplinan pegawai. Pimpinan harus berani dan tegas bertindak untuk menghukum setiap pegawai yang tidak disiplin sesuai dengan sanksi hukuman yang ditetapkan.
\end{abstract}

\section{HASIL PENELITIAN}

Implementasi Peraturan Pemerintah (PP) Nomor 53 tahun 2010 tentang Disiplin Pegawai Negeri Sipil di Lembaga Layanan Pendidikan Tinggi Wilayah II (Studi Kasus Pasal 3).

Dalam penelitian ini ada dua konsep yang digunakan, yaitu:

\section{Implementasi}

Ada empat indikator yang digunakan:

\section{a. Komunikasi}

Komunikasi antar-organisasi dan aktivitas pelaksana merupakan mekanisme yang ampuh dalam implementasi kebijakan publik. Semakin baik komunikasi yang terjalin, maka semakin kecil kesalahankesalahan yang terjadi dalam suatu proses implementasi.

Dalam setiap kesempatan yang ada, para pegawai selalu ditekankan untuk menegakkan aturan yang berlaku. Salah satu contoh adalah setiap tamu tidak diperbolehkan langsung terhubung ke bagian yang ingin dituju. Tamu hanya diperbolehkan melalui humas di bagian depan kantor.

\section{b. Sumber Daya}

Faktor sumber daya mempunyai peranan penting dalam implementasi kebijakan karena bagaimanapun juga jelas dan konsistennya ketentuan-ketentuan atau aturan-aturan suatu kebijakan. Jika para personel yang bertanggung jawab mengimplementasikan kebijakan kurang mempunyai sumber-sumber untuk melakukan pekerjaan secara efektif, maka implementasi kebijakan tersebut tidak akan bisa efektif. 
Sumber-sumber penting dalam implementasi kebijakan yang dimaksud antara lain mencakup:

a) Staf yang harus mempunyai keahlian dan kemampuan untuk bisa melaksanakan tugas;

b) Perintah;

c) Anjuran atasan/pimpinan;

Sumber daya dalam pelaksanaan peraturan, khususnya dalam implementasi Peraturan Pemerintah PP No. 53 Tahun 2010 tentang Disiplin Pegawai Negeri Sipil di Kantor LLDIKTI Wilayah II, terbilang cukup memadai, baik dari sarana dan prasarana yang dimiliki (terutama bangunan gedung yang sudah permanen, atau untuk menunjang pekerjaan seperti laptop dan komputer) maupun sumber daya manusia yang sudah ahli dan berpengalaman di bidangnya.

Dari hasil wawancara di lapangan, penulis menyimpulkan bahwa sarana prasarana di LLDIKTI Wilayah II cukup baik dengan ditandai setiap pegawai ditunjang dengan fasilitas untuk dapat meningkatkan kinerja masing-masing.

\section{c. Disposisi}

Setiap pegawai harus melaksanakan penerapan tentang aturan PP No. 53 tahun 2010 tentang Disiplin Pegawai Negeri Sipil.

\section{d. Struktur Birokrasi}

Penegakan disiplin merupakan amanah dari undang-undang yang berlaku. Banyak pihak yang terhubung selain dari pihak internal, yakni Badan Kepegawaian, dosen, dan pihak yang terhubung dengan LLDIKTI Wilayah II, terutama Kementerian Pendidikan, dan seluruh perguruan tinggi yang ada di Wilayah II.

Dalam rangka mewujudkan PNS yang andal, profesional, dan bermoral sebagai penyelenggara pemerintahan yang menerapkan prinsip-prinsip kepemerintahan yang baik, maka PNS sebagai unsur aparatur negara dituntut untuk setia kepada Pancasila, Undang-Undang Dasar Negara Republik Indonesia 1945, Negara Kesatuan Republik Indonesia, dan Pemerintah, bersikap disiplin, jujur, adil, transparan, dan akuntabel dalam melaksanakan tugas.

Penulis berpendapat bahwa disiplin pegawai di LLDIKTI II bisa dikategorikan cukup baik. Persiapan personel, perbaikan infrastruktur, dan citra yang ditampilkan merupakan modal untuk menjadi tolok ukur pelayanan yang baik.

Pengawasan Pemerintah dalam penelitian ini ditemukan berupa pemberian sanksi, penghargaan, dan pengawasan. Adapun usaha-usaha yang dilakukan oleh Kepala Badan Kepegawaian dalam menggerakkan para pegawai agar dapat bekerja sama mencapai tujuan organisasi adalah: (1) mengikutsertakan para pegawai dalam proses pengambilan keputusan; (2) memecahkan dan mencari solusi atas semua persoalan yang muncul di dalam kehidupan berorganisasi; (3) menciptakan dan memelihara iklim kekeluargaan, kebersamaan, dan kerja sama dalam kehidupan berorganisasi; (4) memotivasi pegawai dengan memperhatikan keinginan, harapan, keperluan dan kebutuhan pegawai yang disesuaikan dengan kemampuan organisasi; dan (5) memberikan kesempatan kepada para pegawai untuk menimba ilmu dan pengetahuan baru serta menggali keterampilan baru. Tidak hanya itu, ada juga usaha-usaha yang dilakukan oleh Badan Kepegawaian untuk meningkatkan kemampuan dan profesionalisme pegawainya, yakni dengan memberikan kesempatan kepada pegawai untuk mengikuti program pendidikan dan pelatihan (diklat).

\section{SIMPULAN}

Berdasarkan hasil penelitian dan pembahasan, dapat disimpulkan bahwa implementasi Peraturan Pemerintah No. 50 tahun 2010 tentang Disiplin Pegawai Negeri Sipil di LLDIKTI Wilayah II Kota Palembang sudah berjalan optimal. Akan tetapi, dalam hal penerapan pelaksanaan disiplin, masih ada beberapa pegawai PNS yang belum secara konsisten dan konsekuen melakukannya dengan baik. 


\section{DAFTAR PUSTAKA}

Arikunto, Suharsimi. (2002) Prosedur Penelitian: Suatu Pendekatan Praktek. Jakarta: Rineka Cipta

Denim, Sudarman. (2002). Metode Penelitian Kualitatif. Bandung: Pustaka Setia

Dwiyanto, Agus; Partini; Ratminto; Wicaksono, Bambang, dan Kusumasari, Bevaola. (2002). Reformasi Birokrasi Publik di Indonesia. Yogyakarta: Pusat Studi Kependudukan dan Kebijakan UGM

Keban, Yeremias T. (2004). Enam Dimensi Strategi Administrasi Publik: Konsep, Teori dan Isu. Yogyakarta: Gava Media

Lubis, Solly. (2007). Kebijakan Publik. Bandung: Mandar Maju Publishing

Nawawi. (2003). Teknik Analisis Data. Jakarta: Graha Ilmu

Nawawi, Hadari. (2003). Metode Penelitian Bidang Sosial. Yogyakarta: Gadjah Mada University Press

Purwanto, Erwan Agus. (2012). Implementasi Kebijakan Publik. Yogyakarta: Gava Media

Redaksi Fokus Media. (2012). Peraturan Disiplin Pegawai Negeri Sipil dan Ketentuan Pelaksanaan. Bandung: Fokus Media

Samsudin, Sadili. (2006). Manajemen Sumber Daya Manusia. Bandung: Pustaka Setia

Sholihul. (2014). Pedoman Penyusunan dan Penilaian SKP (Sasaran Kerja Pegawai). Surabaya: Rona Publishing

Sugiyono. (2006). Metode Penelitian Kuantitatif, Kualitatif, dan RED. Bandung: Alfabeta

Syahruddin. (2009). "Evaluasi Implementasi Kebijakan Pengembangan Kawasan Industri di Kabupaten Karawang”. Tesis. Depok: Fakultas Ilmu Sosial Dan Ilmu Politik Program Studi Ilmu Administrasi Universitas Indonesia 